\title{
キノリノール系有機電界発光素子の 電気伝導に与える電極の効果
}

\author{
正員宮入韭一（信州大） \\ 正員富山正康 (キャノン) \\ 非会員中村紀 和 (新光䨮気工業) \\ 非会員前原隆（新光電気工策）
}

The Effect of Elcctrode Materials on the EL Characteristics of Organic EL Devices having 8-Quinolinol Complexcs as an Emitting Layer

K.Miyairi, Mcmber (Shinshu Univ.), M.Tomiyama, Member (Canon Inc.)

N.Nakamura, Non-member, T.Maehara, Non-member (Shinko Electric Industries CO.,LTD)

In this study, clectric conduction of the organic EL device prepared from 8-quinolinol complexes as an emitting laycr hals becn investigated. As the cathode metal with low work function gives the high luminous efficiency, the barricr between the cathode and the electron transport layer controls the electron injection from the cathodc. Temperature dependence of current density is very weak and activation energy is independent of electrode materials. Electron injection under high electric field is well explained by tunneling theory. Hopping process is proposcd as clectron migration. Holes excessively injected from the anode accumulate in the interface between two organic laycrs and contribute to the enhancement of the electric field at the cathode.

キーワード：有機電界発北素子、電位障壁、トンネル效果、電界強調

\section{1. まえがき}

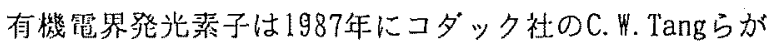
何機材料を朋いた二首槛造の電界発光素子を作成し、実用

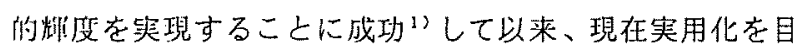
指して砟然が内外で活発に行わ机ている。現在では発光效 率が0.5\%程垃と低く、笑用化には効率を」げると其に経封 変化、酎久性:等についても梌討の必丞がある。高效率化に

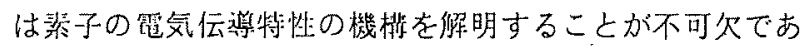
る。本䂨染ではTangらの提唱した二畨樭造の有機電界発光 装子を作成し、その電気伝導機捧を説查することを目的と した。使用する有機材料としては広く一般に用いら机てい

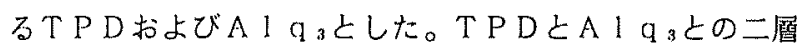
㮐造の有機雷界発光素子はよく使用されている。しかしな

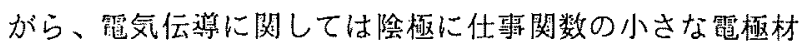

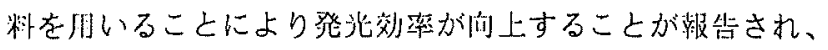

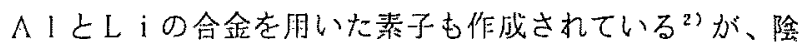

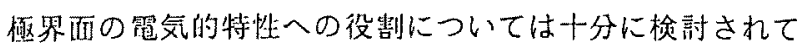
いない。本諭文では有機電界発光素子の発光及び電気伝導

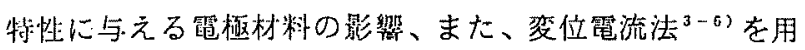

いて電極からのキャリアの注入における電極材料の役割を 調へた。

\section{2. 素子の作成及び実験方法}

\section{〈2.1〉電気伝導特性の測定}

图1には管子渝送性材料である8-キノリノールアルミニウ 么鍇体（A１ａ）と正孔輸送性材料であるテトラフェニル ジアミン（T P D ）の化学啃造を示した。電極ししては陽

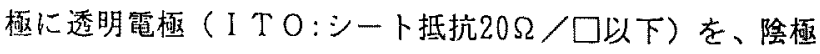
には電極材料の影響を調べるため仕事関数の異なる金属と してアルミニウム、金、マグネシウムを使用した。各層の 膜厚はI T Oが䄪200nmであり、正孔輸送層、電子輸送層及 びA 1、A uは約100nmであるが、M g は約300nm蒸着した ものの上にMgの酸化を防ぐため A g $30 \mathrm{~nm}$ 蒸着した。有 機電界発光素子の画䅡は $0.04 \mathrm{~cm}^{2}$ であり、I TO基板（松浪 ガラス製）上に真学蒸着する前に I T O 基板を洗浄し》、 正孔輸送層、電子輸送層および陰極の順で蒸着した。 有機電界発讣素子に印加する電圧にはパルス電圧を使用 し、パルス振幅を変化させた。パルス電圧のパルス幅は 


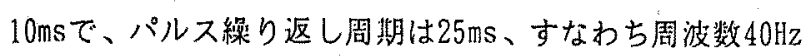
とした。有機雷嘼発光素子の特性の测定は真烓中で行った。

$\langle 2.2\rangle$ 変位䨳流特性の测定

変位電流法による测定に朋いる甚板にはn-Siを與酸化処 理により裴面に厚さ40nmのSiO 2 を形成したものを用意し、 その㜀面の $\mathrm{SiO}_{2}$ をフッ酸（H F) で除去し、下部電極とし

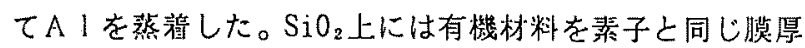
$100 \mathrm{~nm}$ で蒸普し、その上に上部䨮極を蒸着して素子を作成し た。なお、上部電極には主にA１およびA uを使用した。 印加する三㞣波の周波数は0.01Hzとし、測定はすべて真驾 中で行った。なお、基板としてn-Siを使用しているので $\mathrm{SiO}_{2}$ Lの上部霆極に負バイアスを印加したとき、n-Si中の

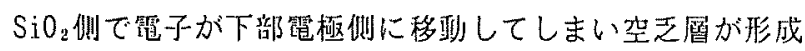
され、容量が咸少して変位電流が減少するので、n-Siの空 无化を防ぐため有機忉料には光吸収によるキャリアの発生 がなく、n-Siではキャリアが発生するような長波長光を照 射し、n-Siに反転状態を形成して测定した ${ }^{3-6) 。 こ の た め ~}$ に照射した赤外LEDのピーク波長は940nmである。

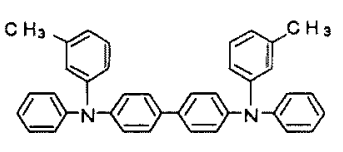

TP D

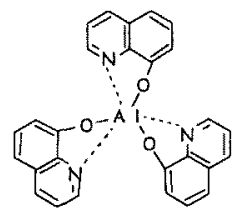

A $1 q_{3}$
图1 TPD及びA $1 \mathrm{q}_{3}$ の化学構造

Fig. 1 Chemical structure of TPD and $A / q_{3}$

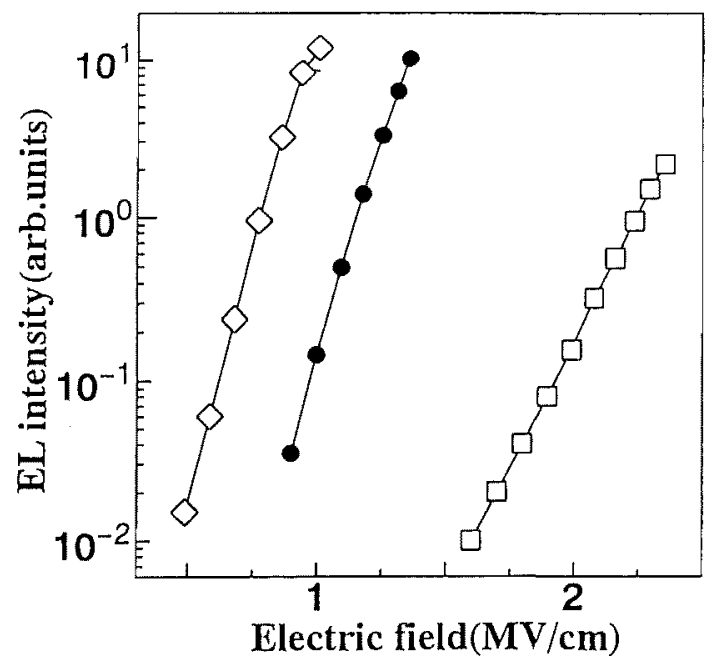

cathode $\diamond: \mathrm{Mg} / \mathrm{Ag} \bigcirc: \mathrm{Al} \square: \mathrm{Au}$

図2 E L 強装一電界特性の電極依存性

Fig.2 Electrode dependence of EL intensityelectric field characteristics
3. 実験結果及び検討

\section{〈3.1〉電気伝導の電極材料依存性}

図2には陰極金属が舅なる有機需界発光素子の発光強度一 䨪界特性を示す。この特性より陰極に用いた電極材料によ って発沦強度一電界特性が変化しており、明らかに電極依存 性が認放られるまた、図了に示す電流密度一電界特性にお いても発光強度の場合と同様に、電極依存性がある。見方 を変えて、発光強度と電流との関係をみると電極材質とは 無関係にほほ同一直線上にあり、発光が注入電流に比例し て行われていることを示している。図2および図3に示した 電極依存性では陰極に用いた金属の仕事関数が小さいほど 発光強度及び電流密度が同一電界に対して大きい值を示し、 陰極一有機界面の電位障壁が電子の注入を支配していること を示している。このことは入力電力に対する発光強度、す なわち素子の発光効率が㓌極に仕事関数の小さな電極材料 を用いることにより高くなることを示している。有機電界 発北素子の実用化に際して発光強度を上げるために高い電 界に扣ける電子的過程を明らかにしておくことは非常に重 要である。電子輸送首にA 1 q 3を用いた素子の電極依存性 の高電界侧に対するショットキープロットを図4に示した。

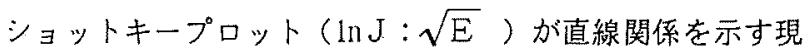
象としてはショットキー効果のほかにプール・フレンケル 効果も考えられる ${ }^{82}$ 。しかしながら、本実験結果は電極依 存性を示しているのでプール・フレンケル效果は否定的で ある。そこでショットキ一效果についてのみ検討する。

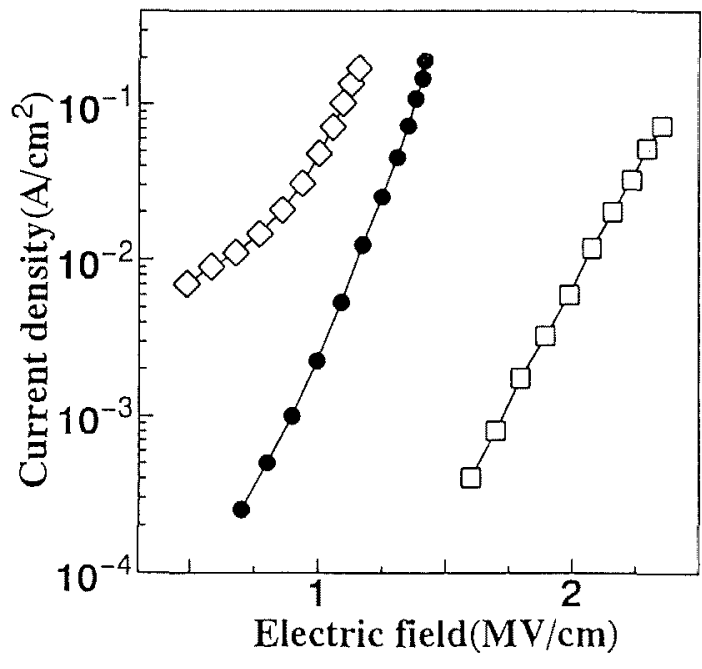

cathode $\diamond: \mathrm{Mg} / \mathrm{Ag}$ ○:Al $\square: \mathrm{Au}$ 図 3 電流密度-電界特性の電極依存性

Fig.3 Electrode dependence of current densityelectric field characteristics 
ショットギ二效果による笔流密度は次式で与元られる。

$$
\begin{aligned}
& J=A T^{2} \exp \left(\frac{\beta_{\mathrm{s}} \sqrt{\mathrm{E}}-\phi_{\mathrm{D}}}{\mathrm{kT}}\right) \\
& \beta_{\mathrm{s}}=\sqrt{\frac{\mathrm{e}^{3}}{4 \pi \varepsilon_{1} \varepsilon_{0}}} \quad \ldots \ldots \ldots \ldots \ldots
\end{aligned}
$$

式(1)、式(2)に従いショットキープロットの傾き $\beta$ sより

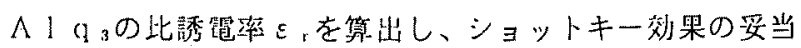
性の碓認を行った。表1には図4の直楾の傾きより求めた比 誘笛率を示した。

裴1ショットキープロットの傾きßsより求めた 比誘雷䧱 $\varepsilon_{\mathrm{r}}$

Table 1 Values of $\varepsilon$, from gradient $\beta_{s}$ of Schottky plots

\begin{tabular}{|c|c|c|c|}
\hline & $\mathrm{Mg} / \mathrm{Ag}$ & $\mathrm{Al}$ & $\mathrm{Au}$ \\
\hline$\varepsilon$, & 1.05 & 0.43 & 0.55 \\
\hline
\end{tabular}

裴にに示したように比誘電率が1程度あるいは1以下の值は物 瑟㢩に不合理であるばかりでなく、変位電流法より求めた

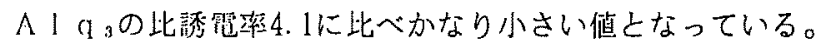
このことより高笔界における電気伝導がショットキ一效果 による電極からの笔子の注入として解积される可能性は少

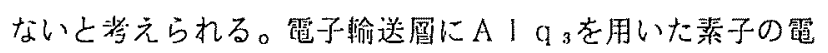
極依存性の藏電界侧に対してファウラープロット

( $\left.\ln \left(\mathrm{J} / \mathrm{E}^{2}\right): 1 / \mathrm{E}\right)$ をした結果を図5に示した。高電界

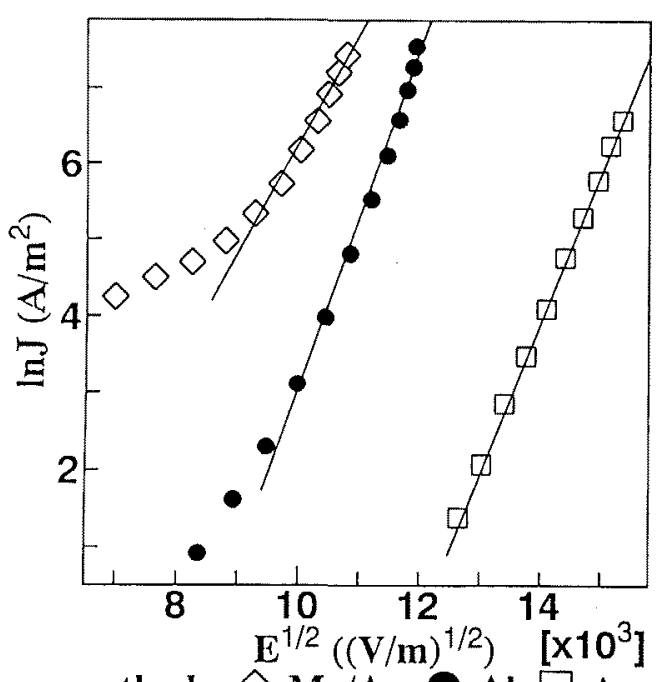

cathode $\diamond: \mathrm{Mg} / \mathrm{Ag}$ :Al $\square: \mathrm{Au}$

図 $4 \mathrm{Alq}_{3}$ 電子輸送層に用いた有機 $\mathrm{EL}$ L䕀子 のショットキープロット

Fig.4 Schottky-plots of current densityelectric field characteristics of ITO/TPD $/ \mathrm{Alq}_{3} /$ cathode
侧でよい直線関係を示しておりトンネル効果が考えられる。 このトンネル効果による電流密度は次式で与えられる。

$$
\begin{aligned}
& J=A E^{2} \exp \langle-B / E\rangle \\
& A=\frac{2.2 \mathrm{e}^{3}}{8 \pi \mathrm{h}_{1} \phi_{\mathrm{D}}} \\
& \mathrm{B}=\frac{8 \pi}{2.96 \mathrm{~h}_{\mathrm{e}} \mathrm{e}}(2 \mathrm{~m})^{1 / 2} \phi_{\mathrm{D}}{ }^{3 / 2}
\end{aligned}
$$

理論式から明らかなように図5の直線より求められる傾き $\mathrm{B}$ は式(5)で表わされ、この傾き $\mathrm{B}$ は $\phi_{\mathrm{D}}$ の3/2乘に比例すると いう関係がある。この $\phi_{\mathrm{D}}$ は電子が除極金属から半導体ある

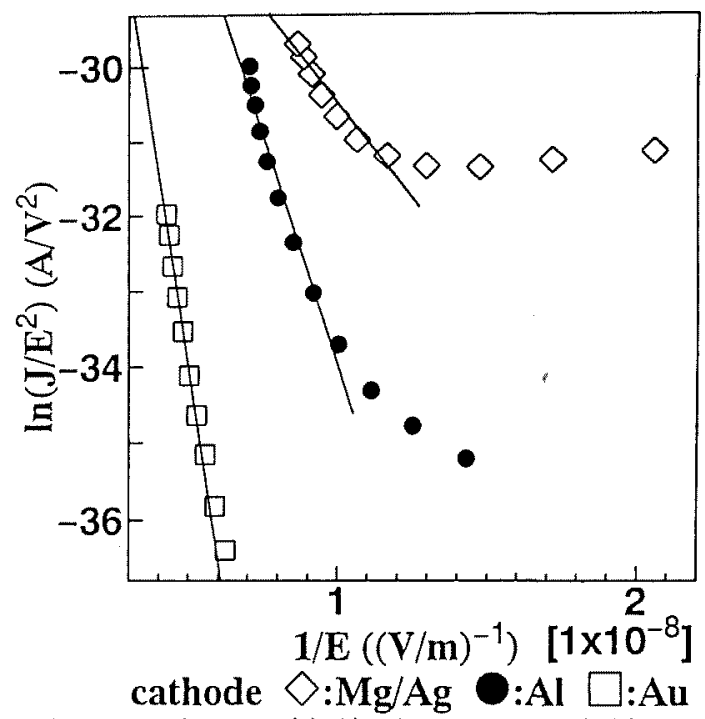

図 $5 \mathrm{Alq}_{3}$ 電子輸送層に用いた有機 $\mathrm{EL}$ 素子 のファウラープロット

Fig.5 Fowler-plots of current densityelectric field characteristics of ITO/TPD $/ \mathrm{Alq}_{3} /$ cathode

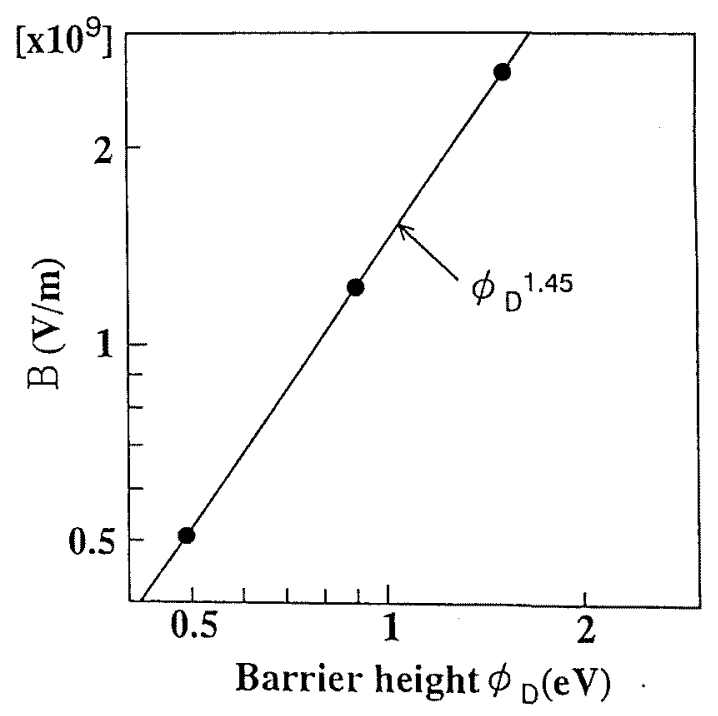

园6 B $-\phi_{D}$ 特性:

Fig.6 $B-\phi_{D}$ characteristic 
いは誘䨪体にトンネルする場合の障壁高さであり、金属の 仕檕阙数から電子䅐和力を引いたものである。一般に有機 分子では1つ1つの分子にエネルギー集位が存在しているが、

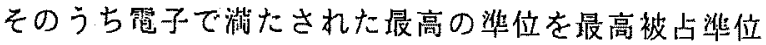
（HＯMO）、些の曼低の準位を最低些準位（LUMO） という。そして、顛㘹燞位からHOMOおよびLUMOま でのエネルギーがそれぞれイオン化ポテンシャル（Is）お よび電子親和力 $(\chi)$ と呼ばれている句。有機分子薄謨は 猬定将の集合体であるため個々の分子間の相互作用により

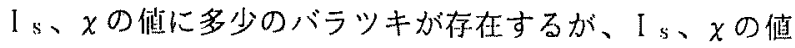
はある值を中心に分布している上考えられる。ここでは测 管された值からエネルギーバンドモデルを適用し、次のよ うな式に煺い電位㜔垶の高さ $\phi_{\mathrm{D}}$ を求如た。

$$
\phi_{1}=\phi_{1 \mathrm{~B}}-\chi=\phi_{\mathrm{n}}-\left(\mathrm{I}_{\mathrm{s}}-\mathrm{E}_{\mathrm{g}}\right)
$$

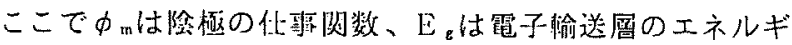
一ギャップである。そこでA１４のイオン化ポテンシャル が5. 66eVである(0)ことから蛍光スペクトルのピーク波辰よ

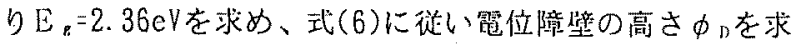
め、裴2に示した。まお、陰極の仕矛関数 $\phi_{\mathrm{m}}$ の值には光電 子枚仙により测定された値、すなわち、Mg、A1およびAuに

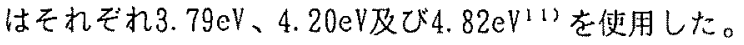

裴2 陰極金属亡霓子漞和力から水少られる 電位障监の高さ $\phi_{0}$

Table 2 values of potential barrier height $\phi_{D}$

\begin{tabular}{|c|c|c|c|}
\hline & $\mathrm{Mg} / \mathrm{Mg}$ & $\mathrm{Al}$ & $\mathrm{Mu}$ \\
\hline$\phi_{\mathrm{D}}(\mathrm{eV})$ & 0.49 & 0.90 & 1.52 \\
\hline
\end{tabular}

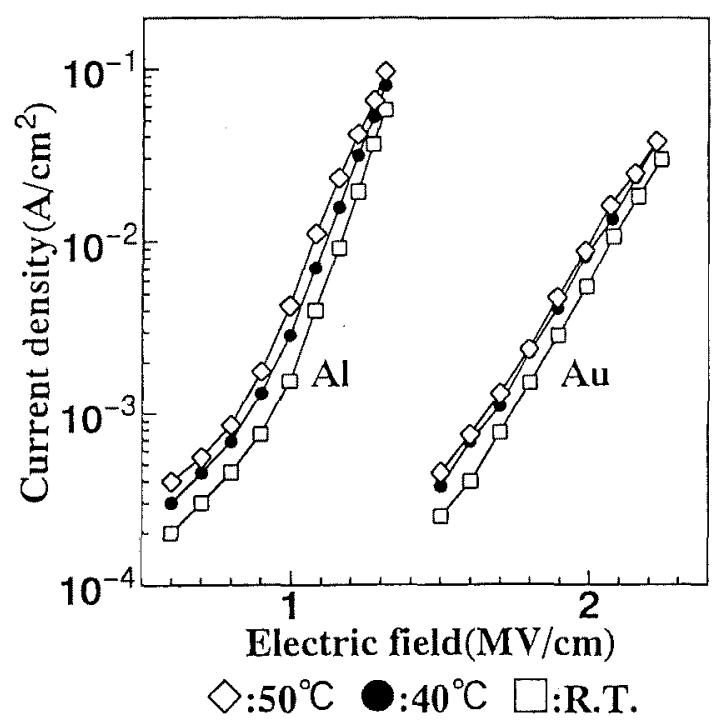

欧7 電流密度-電界特州の温度依存性

Fig. 7 Temperature dependence of current density-electric field characteristics of ITO/TPD/Alq $3 /$ cathode

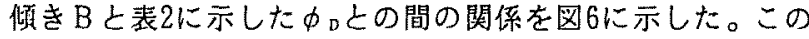
図よりBは $\phi_{D} の 3 / 2$ 乘に比例するという関係がほぼ成り立 っており、有機電界発光素子の高電界における電気伝導は トンネル効果による電流が支配的であることを支持してい るものと考えられる。

\section{〈3.2〉電気伝導の温度依存性}

除極にAおよび $\mathrm{A}$ uを用いた素子の電流密度の温度依 存性の测定結果を図7に示す。温度変化の籍囲はT P D のガ

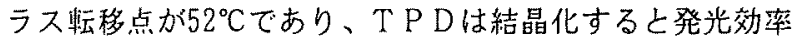
が低下する ${ }^{12)} と の$ 報告があることから室温から $50^{\circ} \mathrm{Cまでと}$

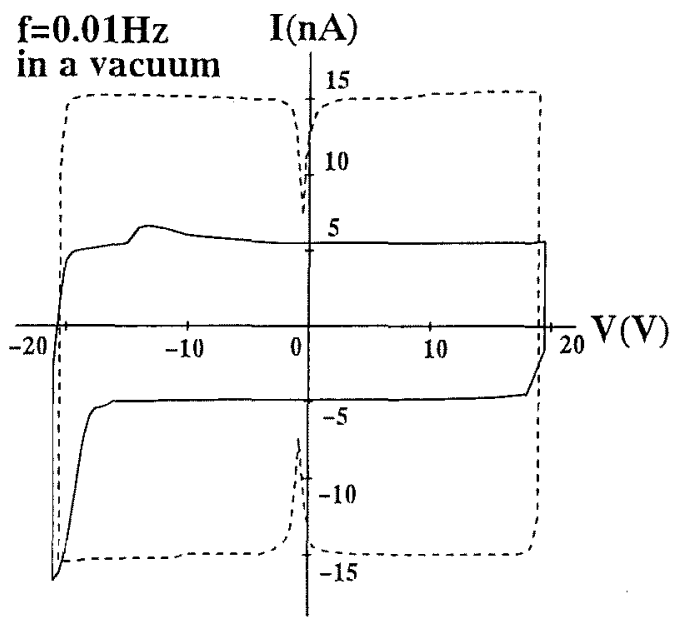

$\mathrm{Al} / \mathrm{SiO}_{2} / \mathbf{n}-\mathrm{Si} / \mathrm{Al}$

$\mathrm{Al} / \mathrm{Alq}_{3} / \mathrm{SiO}_{2} / \mathbf{n}-\mathrm{Si} / \mathrm{Al}$

国 $8 \mathrm{Al} / \mathrm{Alq}_{3} / \mathrm{OS}$ 素子の変位電流特性

Fig.8 Displacement current characteristics of $\mathrm{Al} / \mathrm{Alq}_{3} / \mathrm{OS}$ device

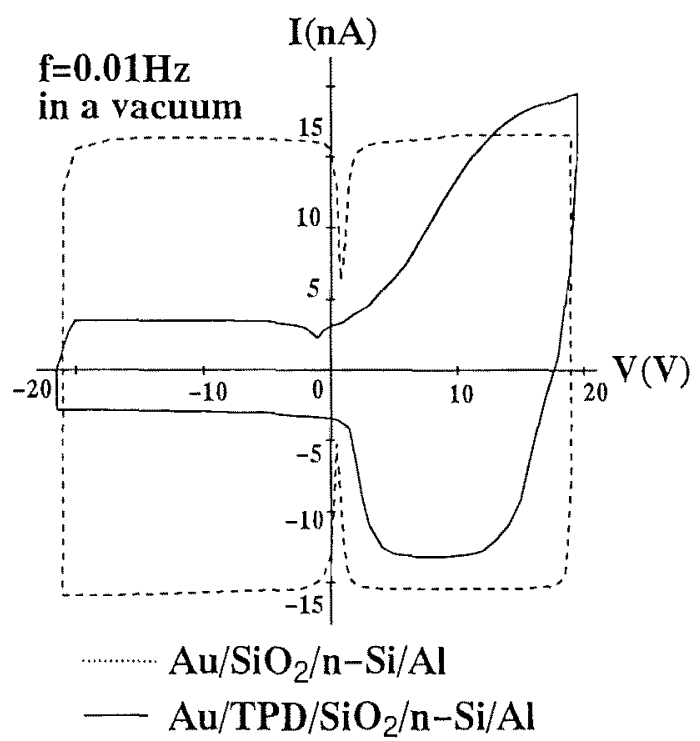

図 $9 \mathrm{Au} / \mathrm{TPD} / \mathrm{OS}$ 秦子の変位電流特性

Fig.9 Displacement current characteristics of Au/TPD/OS device 
した。図7に示した测定結果は電流密度の温度に対する变化 は小さく、特に高電界においてはその変化の割合は小さく なることを示している。このように高電界における電流の 渭度低存性が小さいこともトンネル霓流であることを支持 している。この若下の温度依存性はキャリアの移标に関係 したものと思われる。すなわ方、前述のように本実験で用 いた材料は結晶体ではなく、热定形に近く、多くの不紌物 㳣位が存在する。キャリアの移俥はこの集位をホッピング することによって行われるため熱活性過程が電流の温度依 倞㨫となって現れたものと考えられる。アレニュースプロ ットより電気伝導の活性化エネルギーを求めたところおよ そ0.32eVであり、電極材料に依存していない。すなわち、 注入されたキャリアが有機材料の中を平均0.32evの障壁を ホッピングして移動していくと考えられる。また、本実駼 とは别の高分子を用いた電界発光素子の笔気伝導がトンネ

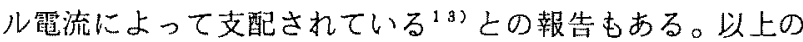

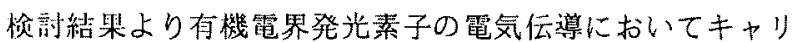
アの注入はトンネル効果によって、また、キャリアの移㽖 はホッピング過程による可能性が大きいと考えられる。

〈3.3〉 変位霆流特性に与える電極材料の影暃

トンネル效果によるキャリア注入の際の電極一有機界面に ついて変位雨流法によって検討した。A I / A l $\mathrm{q}_{3} /$ $\mathrm{SiO}_{2} / \mathrm{n}-\mathrm{Si}$ 素子の变位電流特性孝 $\mathrm{A} 1 / \mathrm{SiO}_{2} / \mathrm{n}-\mathrm{Si}$ 素子の 変位電流特性と合わせて図8に示した。 $\mathrm{SiO}_{2}$ と $\mathrm{Alq}$ ～的を 档層した場合、静電容量の直列接続となるので全容量の減 少により変位電流値が減少するが、上部電極に負バイアス を印加したとき電正上梸洔に電子の注入が観测され、負バ イアスが減少するとき電子の排出が倠测されている。これ

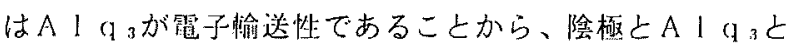
の界面の留位㜔坚を通して電子の注入が存在することを示 している。

$\wedge u / T P D / \mathrm{SiO}_{2} / \mathrm{n} \cdot \mathrm{Si}$ 絜子の変位䨌流特性を $\Lambda u /$ $\mathrm{SiO}_{2} / \mathrm{n}-\mathrm{Si}$ 秦子の変位電流特性と合わせて図9に示した。 $\mathrm{SiO}_{2}$ とTPDとを䅡層した場合にもA $1 \mathrm{Cl}_{3}$ の場合と同様に 桨位管流倠は娍少する。上部電極に正バイアスを印扣した ときに正孔の泟人が観测され、正バイアスの滅少するとき 正孔の排汕が観测され、陽極と T P D との界面には正孔の 注人が存社することがわかる。

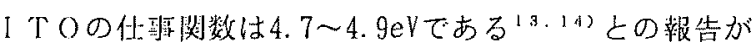
あることからＩTOは仕事関数からみてA1よりむしろ A uに近い。すなわち、A uを用いた場合はほぼ I TOを 陵極に用いた率子の特性と考えてよいものと思われる。変 位笔流特性の結果からA１ａ中にA１から注入される電子 の数に比へ、TPD中にA uより注入される正孔の数はか なり多いことがわかる。また、A１１３は正孔に対しては輸

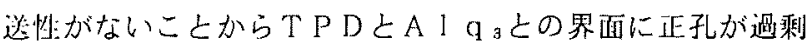
に注人、蓄䅡されて登間電荷となっていることが考えられ る。

〈3.4〉䉓位㜔坚の检討

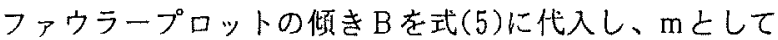

自由電子の質量を用いて電位障壁の高さ $\phi_{\mathrm{D}}$ を求めた結果を 表3に示す。この結果を表 2 と比較すると表 2 に示した りかなり小さい。この原因として有効質量 $\mathrm{m}$ が知られてい ないこと、界面に電荷がトラップされ、界面電界が印加平 均電界と異なっていること等いくつかの原因が考えられる。 このため高電界に抬いてトンネル効果によって電気伝導が 支配されていると定性的には考えられるにしても定量的に はさらに検討を要する。3.3節の変位電流特性で述へたよう に有機界面には電荷の蓄積がある。この蓄積されている正 孔が㓌極電界の大きさに影響を与え、表 2 と表 $3 の$ 電位障壁 の值の差が生ずることも一因であることが考えられる。

表3ファウラープロットの傾き $\mathrm{B}$ を用いて式(5) より計算される電位障壁の高さ $\phi_{\text {。 }}$

Table 3 values of $\phi_{D}$ evaluated from the gradient $B$ of Fowler plots

\begin{tabular}{|c|c|c|c|}
\hline & $\mathrm{Mg} / \mathrm{Ag}$ & $\mathrm{Al}$ & $\mathrm{Au}$ \\
\hline$\phi_{\mathrm{D}}(\mathrm{eV})$ & 0.175 & 0.314 & 0.522 \\
\hline
\end{tabular}

トンネル効果によって電流密度が支配される場合、トンネ ル理諭により計算される電流密度は実測值の電流密度より かなり小さい。T P Dの正孔移動度は $10^{-3} \mathrm{~cm}^{2} / V_{\mathrm{S}}{ }^{152}$ の才一 ダーで大きく、T P D 側の抵抗值は A 1 q sに比べて小さい と思われる。このため印加電界が A I q 側に多く分圧され ることも陰極の電界の変歪に影響していると考えられる。

\section{4.むすび}

本研究の結果をまとめると次のようになる。 (1)電気伝導の電極依存性から㓌極一有機界面は電位障壁に よって電子の注入を支配していることがわかった。高電界 における陰極からの電子の注入についてショットキープロ ットおよびファウラープロットより検討を行った結果、電 子の注入はトンネル効果によって支配されていると理解さ れた。

（2）電気伝導の温度㳖存性から電流の温度依存性は小さく、 活性化エネルギ一は電極材料に依存しないことがわかった。 このことから電子の移動はホッピング過程によって支配さ れていると考えられる。

(3)変位電流法によってキャリアの注人現象についてさらに 検討を行った結果、AＩａは電子輸送性、T P D は正孔輸 送性の確認ができ、陽極からは正孔が過剩に注入されてい ることがわかった。

（4）トンネル效果によって丽気伝導が支配されていると定性 的には理解されるが、定量的には検討を要するが、その原 因としては陽極から過剩に注入された正孔が空間電荷とな って陰極侧の電界強調に寄与していること、電子の有効質 
量が静止質量より小さいことなどが考えられる。

(平成 7 年 3 月 20 日受付)

\section{文献}

1) C. W. Tang and S. A. VanSlyke:" Organic electroluminescent diodes” , Appl. Phys. Lett. ,51, 913-915. 1987

2）村山・川見・永山・米本・舟木・脇本・仲田・今井:" 緑色有機 E L 素子の高輝度・高効率化”，パイオ二ア技報No. 9， $16-23,1994$

3）江草・源間・三浦・東:”有機 E L 素子の動作機構” , 信学技報, OME90-40, 25-30, 1990

4）江草・渡辺・三浦:”有機 E L 素子の接合構造と発光特性 " 信学技報, OME92-19, 19-24, 1992

5）江草:" 有機接合界面の電子物性”, 表面化学, Vol. 15, №. $19,566-572,1994$

6) Syun EGUSA, Akira MIURA, Nobuhi ro GENMA and Makoto AZUMA:" Carrier Injection Characteristics of Organic Electroluminescent Devices" , Jpn. J. Appl. Phys. , 33, 2741-2745, 1994

7）吉見・杉村・森・水谷:" 有機発光素子の高性能化における I T O - T P D 界面制御の効果”，信学技報, OME91-51, $43-48,1991$

8）犬石・中島・川辺・家田: “誘電体現象論”, 電気学会, 220 $-242,1973$

9）岩本・工藤・八瀬: ”有機超薄膜エレクトロニクス”， 培風館, 1-22, 1993

10)佐野・藤田・藤井・西尾・浜田・柴田:”新規キノリノール 錯体系発光材料を用いた有機 E L 素子の評価”， 信学技報, OME92-32, 63-68, 1992

11) H. D. Michaelson, " ELECTRON WORK FUNCTIONS OF THE ELEMENTS" HANDBOOK OF CHEMISTRY AND PHYSICS, 51 , 87-89, 1970

12)吉見・森・水谷: "スクアリリウム色素ドープ有機発光 素子の特性”，信学技報, 0ME92-54, 69-74, 1993

13)I. D. Parker:" Carrier tunneling and device charac teristics in polymer light-emitting diodes" . J. Appl. Phys. , 75, 1656-1666, 1994

14)Ei-ichiro AMINAKA, Tetsuo TSUTSUI and Shogo SAITO, " Electroluminescent Devices Using 9,10-Bisstyrylanthracene Derivatives" , Jpn. J. Appl. Phys. , 33, 1061-1068, 1994

15)森・水谷: ”有機発光素子”，1990年度電気関係学会東海 支部連合大会予稿集S10-13
宮入 圭一

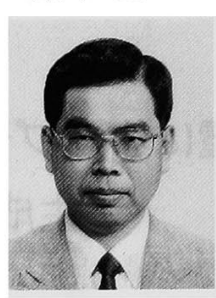

富山正康

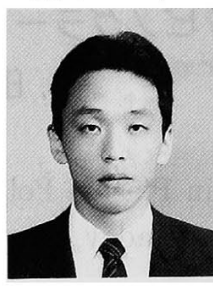

中村 紀和

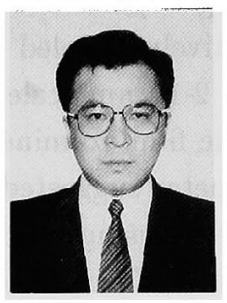

前原隆

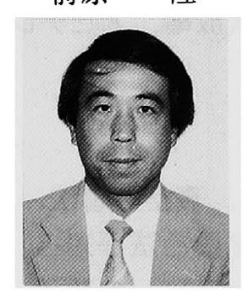

（正員） 1943年5月22日生まれ。72年3 月名古屋大学大学院工学研究科博士課程 修了。工学博士。94年4月信州大学工学部 教授、現在に至る。固体誘電体の電気物 性、特に薄膜の高電界現象に関する研究 に従事。70年電気学会論文賞。応用物理 学会、高分子学会、電子情報通信学会。

（正員） 1970 年4月12日生まれ。95年3月 信州大学大学院工学系研究科博士前期課 程修了。現在、キヤノン（株）に勤務。

非会員）1961年10月28日生まれ。86年 3 月東京都立大学大学院工学研究科修士課 程修了。現在、新光電気工業（株）に勤 務。日本化学会。応用物理学会。

（非会員）1952年8月2日生まれ。77年3 月信州大学大学院工学研究科修士課程修 了。現在、新光電気工業（株）に勤務。 日本化学会。 